В.Є. Шамко, А.В. Антонов

Командування Повітряних Сил Збройних Сил Украӥни, Вінниия

\title{
ПРОБЛЕМНІ ПИТАННЯ ТРАНСФОРМАЦІЇ СИСТЕМИ ВІЙСЬКОВОГО УПРАВЛІННЯ ПОВІТРЯНИХ СИЛ ЗБРОЙНИХ СИЛ УКРАЇНИ НА ШЛЯХУ НАБУТТЯ ВЗАЄМОСУМІСНОСТІ 3 КРАЇНАМИ-ЧЛЕНАМИ НАТО
}

В статті проведено аналіз основних результатів трансформачії системи військового управління Повітряних Сил в 2019-2020 роках з позииї набуття взаємосумісності з системою військового управління НАТО. Розкрито сутність удосконалення системи військового управління Повітряних Сил Збройних Сил Украӥни, основні завдання, виконані заходи та напрямки подальших дій щодо набуття взаємосумісності.

Ключові слова: адаптація, взаємосумісність, Повітряні Сили, система управління.

Удосконалюватися - значить змінюватися, бути досконалим - значить змінюватися часто. Уінстон Черчилль

\section{Вступ}

Постановка проблеми. Агресія Російської Федерації проти нашої країни, окупація Автономної Республіки Крим та окремих районів Донецької та Луганської областей, сім років проведення антитерористичної операції (операції Об'єднаних Сил) створили суспільний запит на набуття членства України у євроатлантичних спільнотах, як найбільш дієвого шляху забезпечення національного суверенітету, захисту цінностей і способу життя, який обрав народ України [1]. Набуття членства в НАТО є закріпленою в Конституції України та інших нормативно-правових актах нормою [2-3], проте цей шлях $\epsilon$ складним через низку політичних, економічних та військових зовнішніх й внутрішніх чинників, зокрема в частині, що стосується невідповідності принципів побудови та функціонування системи об'єднаного керівництва силами оборони та військового управління у Збройних Силах України та HATO.

Звертаючись до історії біполярного світу (СРСР та США), можна констатувати той факт, що системи військового управління цих країн кардинально різнилися [4]. Це стало об'єктивним наслідком “ізольованого” розвитку в країнах східного і західного блоків науки про військове управління під впливом праць таких теоретиків як О.А. Свечін, П. Друкер, Дж. Бойд, а також завдань, які ставилися перед збройними силами в період холодної війни. На сьогоднішній день система військового управління Збройних Сил (3С) України в цілому та Повітряних Сил (ПС) зокрема, що була побудована на основі принципів функціонування успадкованих 3 радянських часів, проходить важкий шлях трансфо- рмації для досягнення взаємосумісності зі збройними силами країн-членів НАТО, як необхідної передумови набуття членства в даному блоці.

Таким чином, оцінка стану трансформації системи військового управління ПС ЗС України та вироблення рекомендацій щодо іiі удосконалення в рамках набуття взаємосумістності 3 країнамичленами НАТО є метою статті.

Аналіз останніх досліджень і публікацій. Звертаючись до літературних джерел, які були використані в статті, умовно їх можна розділити на декілька груп:

- до першої групи відносяться теоретичні роботи з менеджменту, військового управління, розвитку систем управління [5-8], які використані для розуміння загальних тенденцій розвитку наукових моделей та методів у менеджменті;

- друга група робіт представлена стандартами та настановами щодо організації планування та військового управління, прийнятих в країнах - членах НАТО [9-11], які використані для аналізу моделі військового управління;

- третя група джерел складається 3 оновленої доктринальної бази Повітряних Сил Збройних Сил України [12], яка використана для оцінки стану системи військового управління за підсумками іiі трансформації в 2019-2020 роках.

\section{Виклад основного матеріалу}

\section{Принципи військового управління}

Оцінка тенденцій у сфері міжнародної та національної безпеки, а також особливостей ії розвитку призвели до того, що багато держав ще з кінця XX століття стали переживати глибокі структурні зміни в різних сферах життя суспільства, в тому числі в сфері збройної боротьби. Ці зміни носять фундаментальний характер, порівнянний, наприклад, з винаходом вогнепальної зброї та його масовим викорис- 
танням у воєнних цілях, і зв'язуються головним чином 3 широким прикладним використанням результатів наукових досліджень і досягнень у сфері інформатизації, що зумовили перехід від постіндустріального суспільства до інформаційної епохи. Революція в інформаційній сфері вплинула на методи організації збройної боротьби, з'явилася можливість удосконалювати форми організації управління військами та зброєю. Збройні сили США, які є на сьогоднішній день найбільш технічно оснащеними, лідирують у формуванні сучасних доктрин, стратегій та концепцій будівництва $3 \mathrm{C}$, у тому числі і для

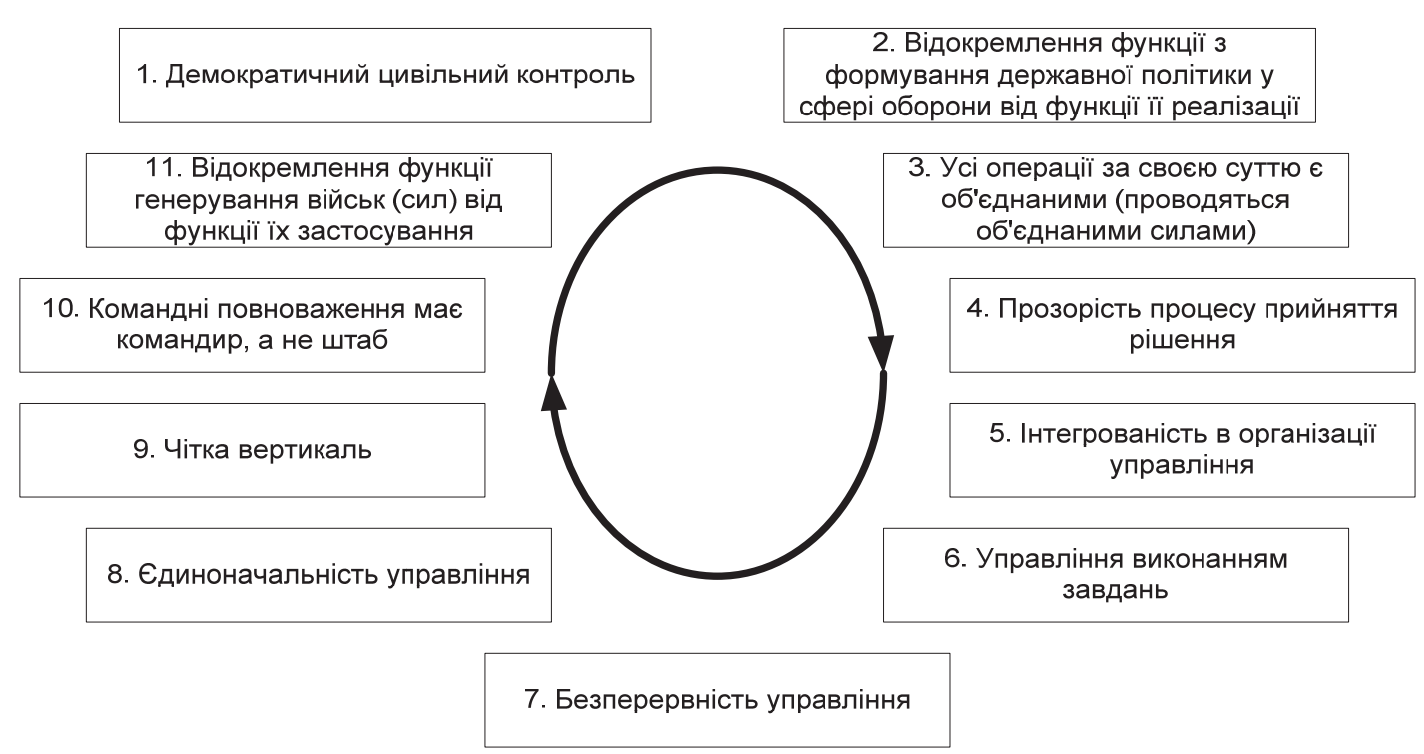

Рис. 1. Основні принципи військового управління, які є критичними для набуття взаємосумісності з НАТО в сфері військового управління Джерело: розроблено авторами.

Слід зазначити, що зазначені принципи в переважній більшості не є абсолютно новими для ПС ЗС України. Частина з них вже була притаманна системі військового управління 3С України. Над певними напрямками була проведена значна робота в рамках реалізації Програми створення системи об'єднаного керівництва силами оборони та військового управління у ЗС України, що була ініційована рішенням начальника Генерального штабу - Головнокомандувача 3С України від 05 червня 2019 року з метою реалізації рекомендацій наших партнерів та на виконання наказу Міністерства оборони України від 26.03.2019 №141 “Про трансформацію системи об'єднаного керівництва силами оборони та військового управління у ЗС України".

Лише один управлінський принцип НАТО ще не зазнав практичних кроків для імплементації, це Mission Command (управління виконанням завдань, або принцип директивного/децентралізованого управління, централізованого управління - децентралізованого виконання, тощо). Навіть більше, ми i досі не впровадили усталеного україномовного терміну. Проте за свідченнями наших партнерів, він $\epsilon$ одним з найскладніших для впровадження, оскільки інших держав, в першу чергу членів НАТО.

У рамках створення нової теоретичної бази в інформаційну епоху по-іншому розуміються основні принципи управління збройною боротьбою. На рис. 1 наведені основні принципи військового управління, які були визначені в заключному звіті міжнародної консультативно-дорадчої групи з військового управління, що був виданий за результатами іiі роботи наприкінці 2018 року. В зазначеному звіті українській стороні було рекомендовано здійснити їх імплементацію з метою набуття взаємосумісності з НАТО в сфері військового управління. формування державної політики у

Усі операції за своєю суттю $€$ сднаними (проводяться рішення

відображає філософію управління, тому робота над його впровадженням в практику управлінської діяльності цілком обгрунтовано займе роки.

Водночас саме цей філософський підхід багато в чому обумовлює решту управлінських принципів, тому доцільно більш детально розкрити його сутність.

Із усієї множини характеристик, які визначають найбільш істотні риси принципів військового управління, можна виділити три ключові:

а) розподіл прав прийняття рішення;

б) організація взаємодії (співробітництва) між особами, що приймають участь у підготовці (вироблення) рішень;

в) розподіл інформації між учасниками процесу управління.

Дані характеристики формують тривимірний простір, у якому можна представити різні типи управління військами [3]. Місце розташування організації в просторі типів управління військами відображається як відносно окремих функцій управління, так і відносно динаміки переходу від одного типу управління до іншого.

Можливий розподіл прав прийняття рішення 
має два протилежних логічних полюси. Один полюс - повна централізація (усі права прийняття рішень зосереджені в однієї особі). Інший полюс - повна децентралізація (кожний учасник управлінського процесу має рівні права у прийнятті рішення).

Для військового управління в індустріальній епосі (XX століття) характерна висока концентрація управлінських функцій. При існуючих технічних обмеженнях на темп обробки й доставки інформації орган управління був монополістом на найбільш повну інформацію. Тільки він, забезпечений найбільш повною інформацією, міг виробити найкраще (оптимальне або раціональне) рішення. У такій системі управління вся інформація збиралася в центрі, перетворювалася до виду, зручного для вироблення рішення, а потім у вигляді детальних директив i планів доводилася військам (силам). Така філософія управлінської діяльності в збройних силах країн світу отримала назву Detailed Command (централізоване деталізоване управління).

Тому для 3С індустріальної епохи, до яких можна віднести ЗС України до початку трансформації iii системи військового управління, характерна централізація права прийняття рішень. Відображенням стилю централізації ЗС цієї епохи була практика видання наказів (розпоряджень) від імені командиpa, навіть коли накази стосувалися деякої спеціалізованої функціональної області.

Водночас суттєві зміни в операційному середовищі сучасних збройних конфліктів, зокрема збільшення їх динамізму, обумовленого технологічним прогресом, ускладнення, пов'язані із збільшенням розмаїтості засобів і способів дій асиметричних сил конфліктуючих сторін, збільшення невизначеності в діях протилежної сторони (“туману війни”) призводять до того, що централізоване деталізоване управління стає неефективним і не дозволяє адекватно реагувати на швидкі зміни в обстановці. Тому у 3С інформаційної епохи на зміну ієрархічним системам взаємодії (співробітництва) приходять мережні структури взаємодії.

3С країн НАТО та інших держав (але у різному ступені) перебувають у стані перетворення (трансформації) від так званих ЗС індустріальної епохи до ЗС постіндустріальної (інформаційної) епохи і впроваджують принципи децентралізації управлінських функцій на виконавчому рівні. Тенденція еволюції класичного управління військами від централізованого до децентралізованого мережевого управління можна розглядати як процес адаптації військових організацій до змін, які відбуваються в операційному навколишньому середовищі.

Нова філософія військового управління отримала назву Mission Command. Ïї ключовими ознаками $\epsilon$ :

- командна робота на основі взаємної довіри (як на горизонтальних, так і на вертикальних рівнях ієрархії, як з боку підлеглих до начальників, так i навпаки);

- узгоджене розуміння спільної мети та замислу (намірів) старшого командира;

- ініціатива на місцях в досягненні спільної мети (іноді навіть всупереч попереднім директивам, якщо своєчасні дії на місцях дозволять використати “вікна можливостей” для найбільш ефективного досягнення кінцевої мети та в межах намірів старшого командира);

- опрацювання директивно-розпорядчих документів в форматі, що відображають наміри командира, а не порядок їх виконання, тобто 5W (Хто, Що, Де, Коли і Для чого) замість 5WH (Хто, Що, Де, Коли, Для чого і Як);

- високий рівень компетенції усіх учасників управлінського процесу (як правило на два рівні вище займаної посади);

- готовність до “розумних ризиків” (як з боку підлеглих під час вироблення рішень для найбільш раціонального виконання завдань, так і з боку командирів, що делегують відповідні права на нижчі рівні).

Слід зазначити, що хоча Mission Command як управлінський принцип став системно впроваджуватись в практику функціонування систем військового управління країн НАТО лише протягом останніх 2030 років, сам принцип не є новим, а походить від принципу німецького оперативного мистецтва 19 сторіччя Auftragstactik (тактика доручень).

Даний принцип був відомий ще 3 часів Сунь Цзи: “...якщо всі зосереджені на одному, сміливий не може один виступити вперед, боягуз не може один відійти назад...”.

Проте лише масштабний технологічний прогрес, пов'язаний з переходом суспільства до постіндустріальної (інформаційної) епохи дозволив створити необхідну технічну базу для його широкого впровадження. Більш того, хоча принцип Mission Command i протиставляється принципу Detailed Command, проте не заперечує його. Доктринальні документі ЗС США та інших країн НАТО розглядають обидва принципи як такі, що можуть застосовуватись в управлінській діяльності в залежності від обставин. У більш статичному операційному навколишньому середовищі переважає централізоване прийняття рішення, у якому дії військ можуть бути оптимізовані на основі найбільш повної інформації, якою володіє центр. Однак у динамічному операційному навколишньому середовищі централізоване прийняття рішення може виявлятися не своєчасним для ведення успішних бойових дій. Тим не менш caмe Mission Command визначається найбільш пріоритетним для використання за рівних умов.

Отже, центральним моментом у розумінні того, 
як відбувається розвиток управління військами в сучасних умовах, є усвідомлення раціональності в розподілі прав прийняття рішень, у виборі структури і схеми взаємодії (співробітництва) у ході підготовки та прийняття рішень, а також проведення розподілу необхідної інформації адекватно зовнішній операційній обстановці.

\section{Принципи побудови системи військового управління}

Виходячи 3 наведених теоретичних положень, відмітимо особливості побудови органів військового управління НАТО та країн партнерів. Загальне керівництво об'єднаними збройними силами (ОЗС) НАТО здійснює північно-атлантична рада через військовий комітет НАТО. Північно-атлантична рада $є$ органом управління стратегічного політичного рівня. Військовий комітет НАТО, в свою чергу, є стратегічним військово-політичним органом управління НАТО.

Військова складова стратегічної ланки управління представлена двома стратегічними командуваннями НАТО. Союзницьке командування трансформації є органом управління генеруванням спільних спроможностей та відповідає за забезпечення сталого розвитку НАТО та країн-членів, досягнення взаємосумісності збройних сил, розвиток їх спроможностей, тощо. Штаб квартира Командування трансформації розташована в м. Норфолк, штат Вірджинія, США. Союзницьке командування операцій $\epsilon$ органом управління застосуванням та відповідає за планування та проведення усіх військових операцій НАТО. Очолює це командування Верховний командувач НАТО в Європі, який, не зважаючи на історично успадковану назву посади, є Головнокомандувачем усіх ОЗС НАТО. Штаб-квартира командування знаходиться в м. Монс в Бельгії.

Оперативна ланка управління НАТО представлена на поточний момент трьома Об'єднаними (або міжвидовими) оперативними командуваннями, що розташовані в містах Брунсум, Неаполь та Норфолк. До оперативно-тактичної ланки відносяться командування видів (або компонент) збройних сил, зокрема: Сухопутних військ в м. Ізмір, Повітряних Сил в м. Рамштайн та ВМС в м. Норсвуд. Додатково в підпорядкуванні Командування ПС НАТО є три багатонаціональних центри повітряних операцій: два стаціонарних в містах Уедем та Торрейхон, а також мобільний центр повітряних операцій.

Крім того, до оперативно-тактичної ланки відноситься Командування Сил спеціальних операцій, проте воно не має сталого місця дислокації, а на ротаційній основі щороку одна з країн НАТО на базі власних Командувань ССО розгортає відповідний орган управління. Доцільно відзначити, що наведена структура органів управління дозволяє НАТО проводити до 3-х повномасштабних військових операцій та/або до шести-дев'яти малих операцій з кризового реагування одночасно, що відповідає задекларованому рівню військових амбіцій НАТО. Тобто кожне 3 трьох Об'єднаних оперативних командувань має спроможності з ведення однієї великої та до трьох малих міжвидових операцій одночасно. Видові командування мають спроможності з виділення відповідної складової системи управління для їх підтримки та забезпечення (рис. 2).

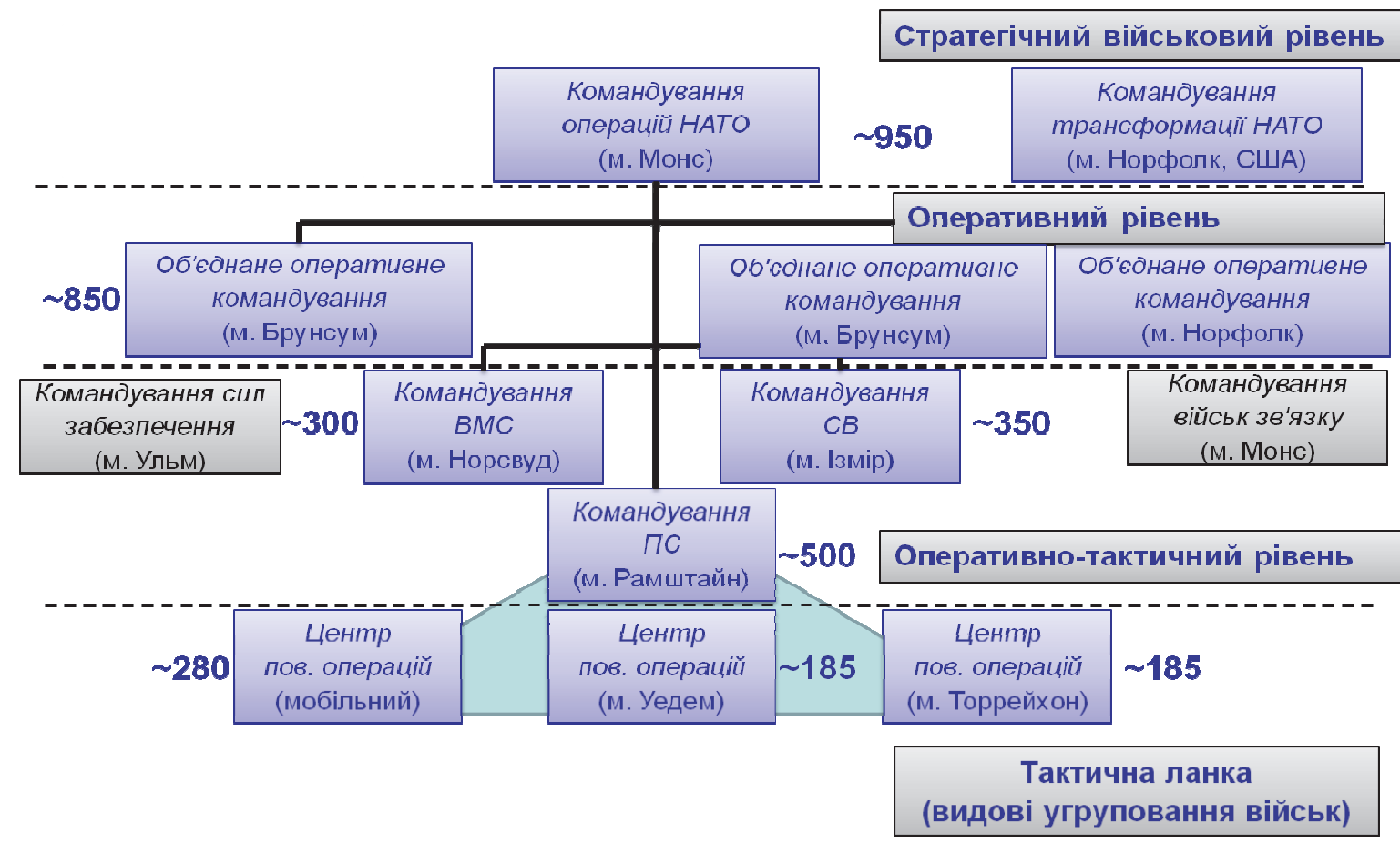

Рис. 2. Структура органів управління НАТО

Джерело: розроблено авторами. 
Таким чином, наведена структура відображає реалізацію одного з ключових принципів побудови і функціонування системи військового управління НАТО, а саме чітке розмежування функцій управління генеруванням та застосуванням військ.

Зазначений принцип також зазнав імплементації в ході реалізації Програми створення системи об’єднаного керівництва силами оборони та військового управління у ЗС України і був однією з двох стратегічних цілей трансформації системи військового управління ПС ЗС України.

Для реалізації зазначеної цілі була сформована модель управління, що представлена на рис. 3.

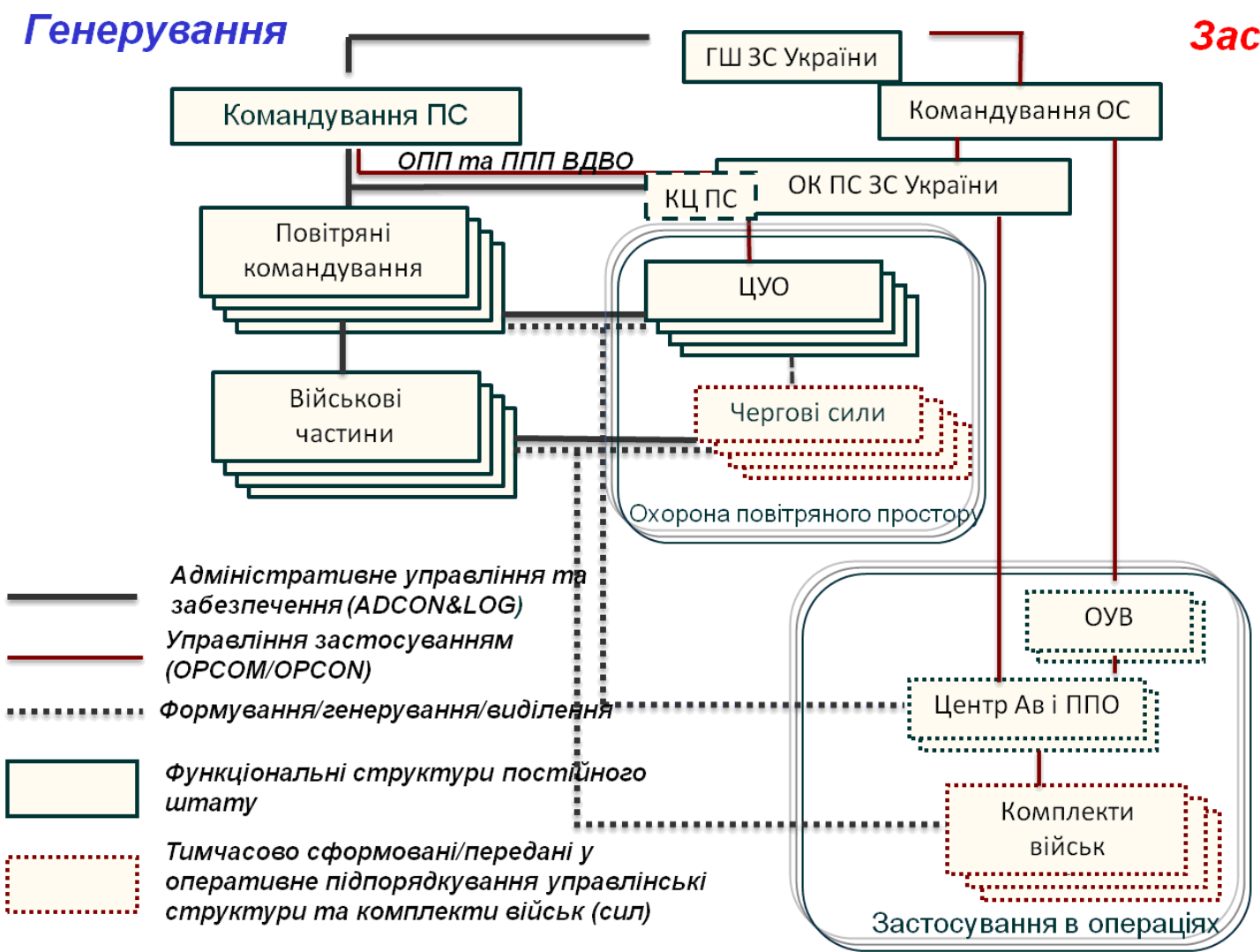

Рис. 3. Модель управління Повітряних Сил Збройних Сил України

Джерело: розроблено авторами.

Водночас реалізована схема має певні недоліки, оскільки фактично виключає охорону повітряного простору та протиповітряне прикриття з системи застосування ПС ЗС України. Це призводить до того, що за певних сценаріїв (зокрема повномасштабного збройного конфлікту з широким застосуванням засобів повітряного нападу з боку агресора) частина повітряного простору держави виключається $з$ зони проведення операції об'єднаних сил і як наслідок:

- повітряний простір держави ділиться на дві зони з різним правовим статусом: в одній продовжується ведення охорони повітряного простору під керівництвом командувача ПС ЗС України, в іншій ведеться протиповітряна оборона під керівництвом командувача Об'єднаних Сил;

- розподіл на зони прив'язується до зони проведення операцій Об'єднаних сил на суходолі i, як наслідок, не враховується специфіка ведення збройної боротьби в повітряному просторі;

- формується два незалежних угруповання повітряних сил, що призводить до розосередження та децентралізації зусиль і вкрай обмежених сил і засобів.
Таким чином, враховуючи відсутність на території держави значних природних перешкод (гірських масивів) для ведення збройної боротьби в повітряному просторі, а також те, що рубежі досяжності засобів повітряного нападу РФ проходять по м. Львів (та перекривають усю територію країни за умови використання оперативних аеродромів на території союзників РФ по ОДКБ), такий підхід може потенційно знижувати ефективність відбиття ударів повітряного противника.

Окремим проблемним питанням $є$ обмежені спроможності Командування ПС ЗС України 3 управління угрупованнями в ході відбиття ударів повітряного противника в своїй зоні відповідальності за умови передачі операційного Командування ПС ЗС України в оперативне підпорядкування командувачу Об'єднаних сил, оскільки його структура була оптимізована для виконання функцій генерування. Командний центр ПС для виконання функцій управління черговими силами 3 охорони повітряного простору формується операційним Командуванням ПС, проте з його убуттям у визначені операцій- 
ні райони комплектування чергових змін значно ускладнюється.

Вирішення зазначеного проблемного питання може полягати в наступному:

- за умови реалізації сценарію повномасштабного збройного конфлікту з широким застосуванням засобів повітряного нападу з боку агресора весь повітряний простір держави має розглядатися як район ведення бойових дій (протиповітряної оборони) i відповідно бути зоною відповідальності операційного Командування ПС ЗС України (незалежно від поділу на райони проведення операцій на суходолі);

- після завершення набуття спроможностей операційним Командуванням ПС ЗС України передати йому функції охорони повітряного простору та протиповітряного прикриття важливих державних та військових об'єктів.

Слід зазначити, що охорона повітряного простору (Air Policing), а також протиповітряна та протиракетна оборона (в тому числі в мирний час) в країнах НАТО відноситься до системи застосування і покладена на відповідні органи управління застосуванням (NORAD, NATO Allied Air Command, тощо), тому реалізація наведених вище пропозицій дозволить досягти більш повної сумісності з країнами-партнерами.

\section{Принципи побудови органів військового управління}

Другою стратегічною ціллю трансформації системи військового управління ПС ЗС України передбачалося досягнення функціональної сумісності iiі органів військового управління з органами військового управління НАТО, в першу чергу уніфікації структури їх штабів.

На рис. 4 наведена типова організаційноштатна структура штабів органів військового управління НАТО. Вона дозволяє розділити повноваження та відповідальність між командувачем та начальником штабу, реалізувати принципи функціонального розподілу і забезпечити норми керованості.

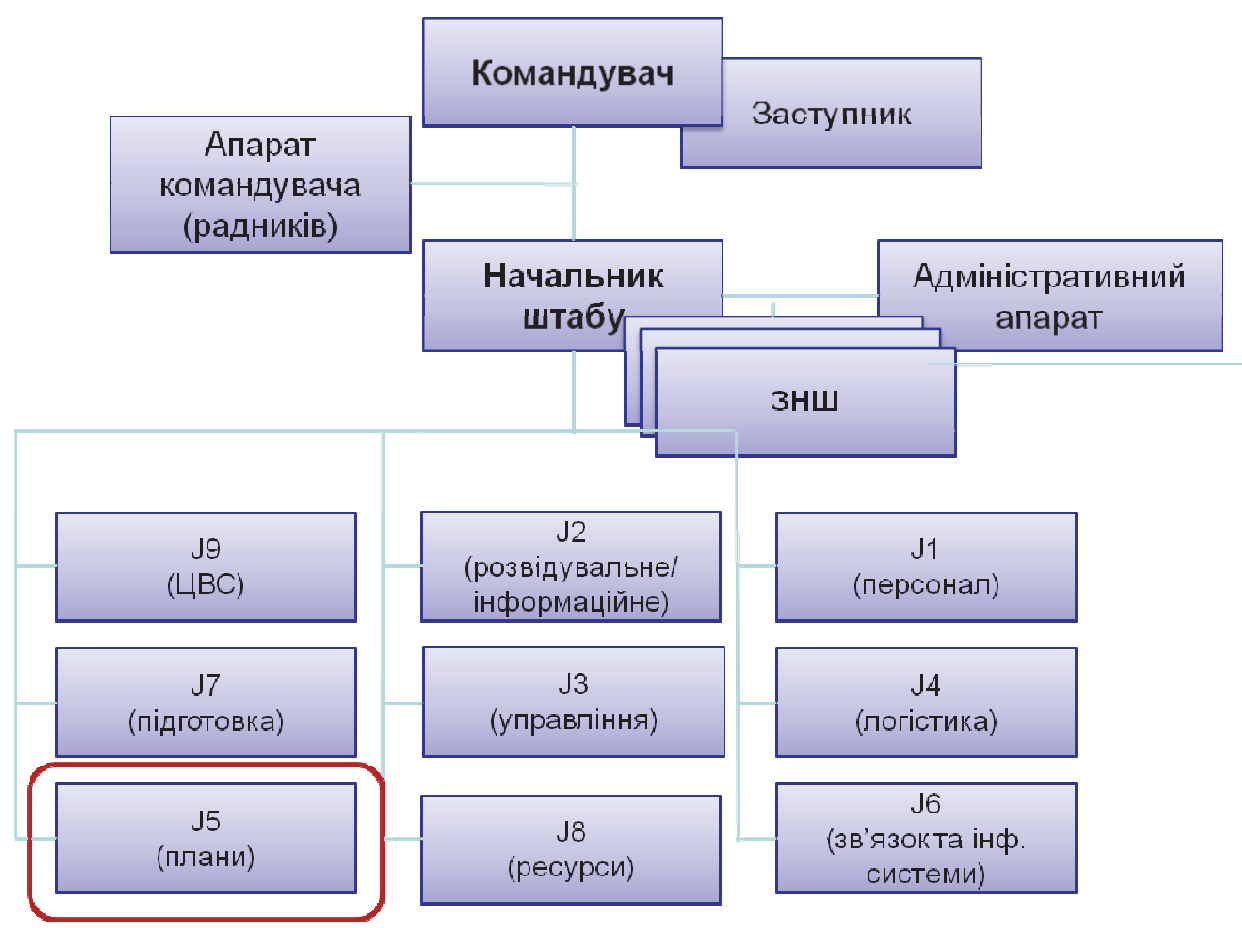

Рис. 4. Типова організаційно-штатна структура штабів органів військового управління НАТО Джерело: розроблено авторами.

Структурно в діяльності штабу виділяються три загальних напрямки роботи, які очолюються відповідними заступниками: це всебічне планування, організація оперативної роботи та організація всебічного забезпечення.

Слід зазначити, що в залежності від ланки системи управління та приналежності структура штабів може варіюватися, тобто наведена типова схема - це лише загальноприйнятий шаблон.

Основним структурним підрозділом будь-якого штабу є підрозділ планування (J5), а також управ- ління (J3).

Структура органу управління застосуванням на тактичному рівні (в угрупованні об'єднаних сил) наведена на рис. 5. В цілому вона уніфікована зі структурою органів управління вищої ланки, за винятком посилення оперативної складової додатковим підрозділом безпосереднього планування та вилучення зі складу цього органу управління структурних підрозділів, які не здійснюють планування застосування, забезпечення та управління військами, як-то управління підготовки, персоналу, тощо. 


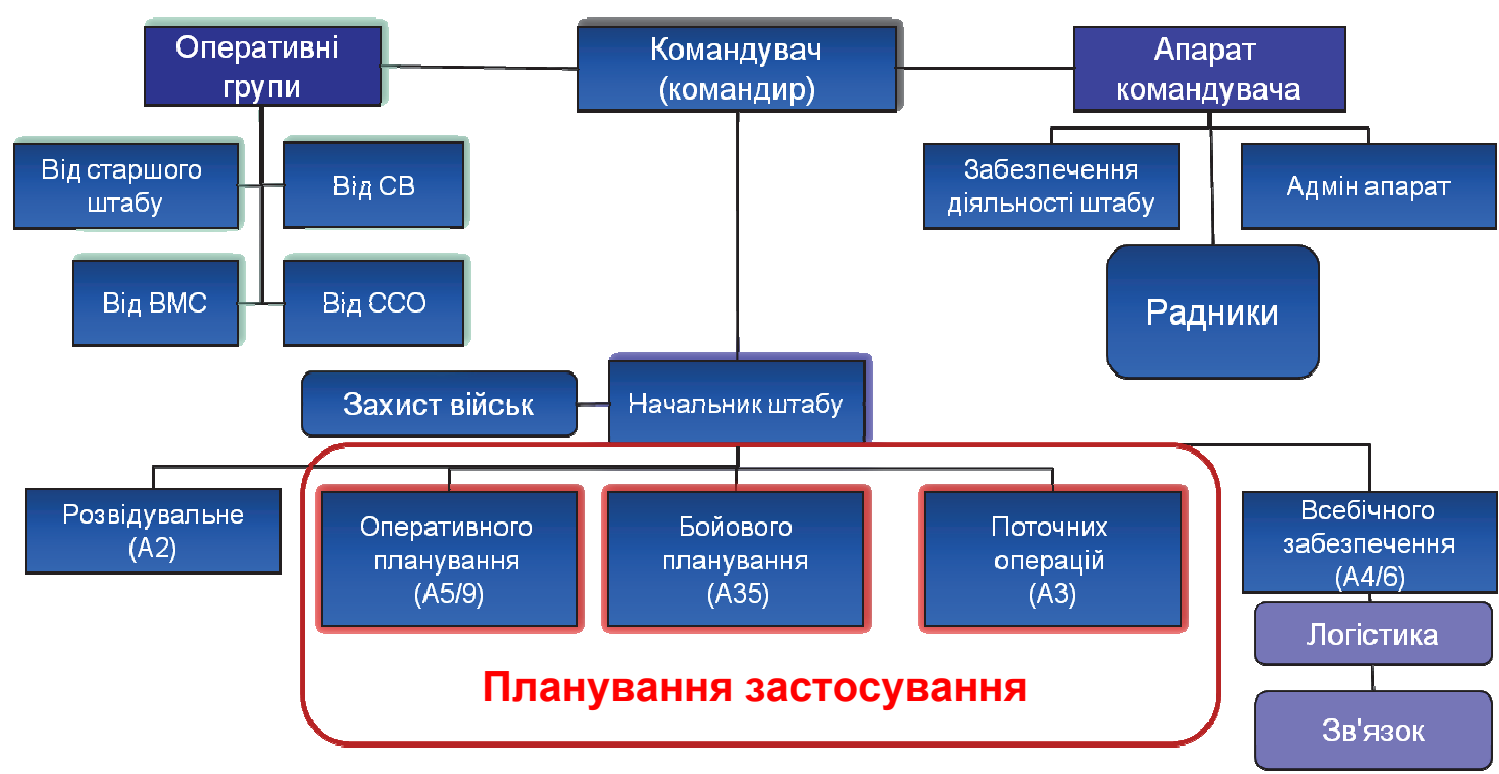

Рис. 5. Типова організаційно-штатна структура органів управління повітряною компонентою НАТО тактичної ланки

Джерело: розроблено авторами.

Як зазначено на рис. 5, за планування та координацію застосування підпорядкованих військ у складі цього органу управління відповідають три окремих структурних підрозділи: стратегічного та бойового планування і поточних операцій.

Розподіл обов'язків та повноважень між ними наведений на рис. 6.

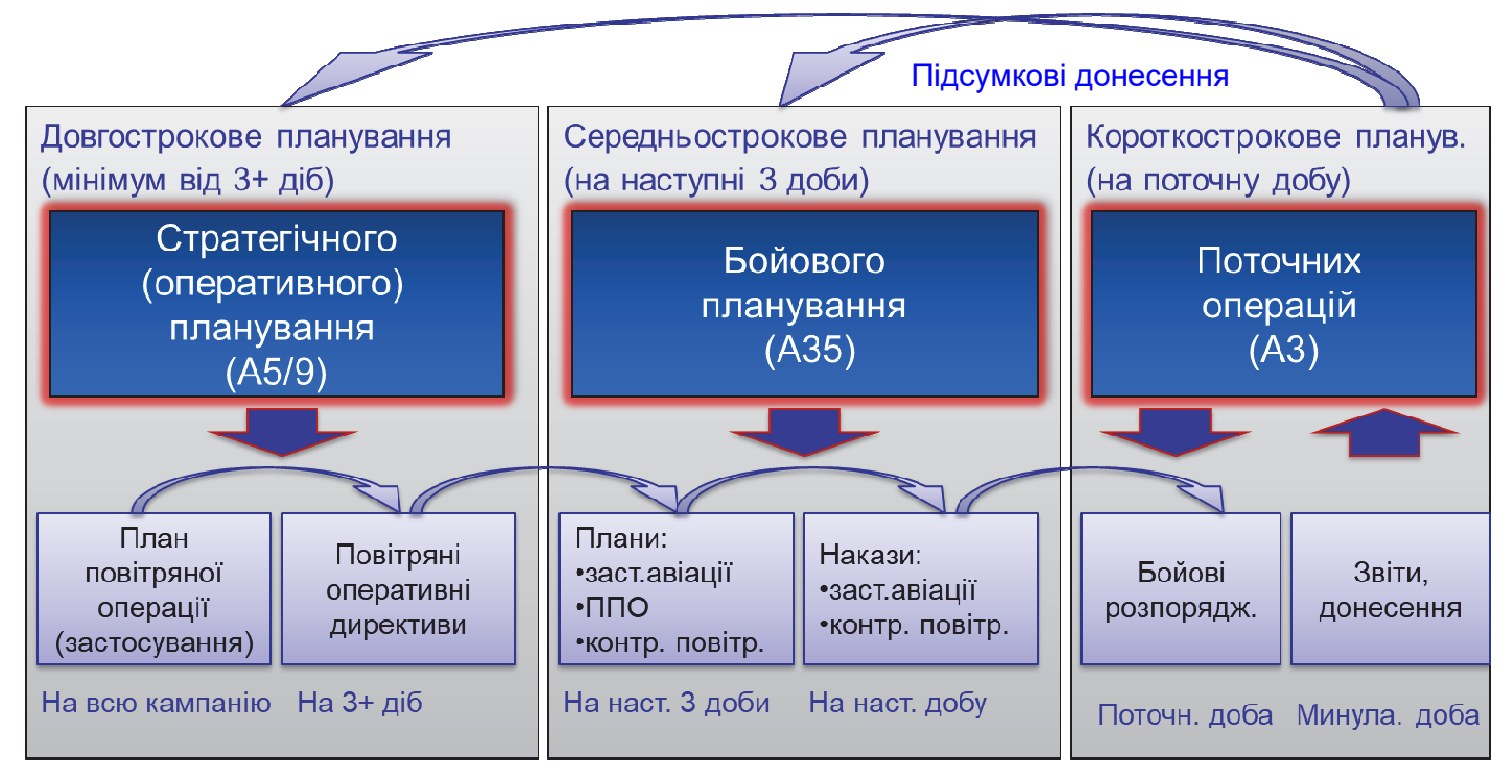

Рис. 6. Розподіл відповідальності структурних підрозділів ОВУ

за планування/ведення операцій

Джерело: розроблено авторами.

Слід зазначити, що в цілому структура органів управління застосуванням ПС ЗС України (операційного Командування та управлінь ПвК) наближена до структури відповідних органів військового управління НАТО. Проте існує ряд недоліків, над усуненням яких доцільно продовжити роботу, це:

- функції підрозділів А5 в основному обмежені бойовим плануванням, тобто вони виконують функ- ції підрозділу А35, а функції оперативного планування перебрало на себе Командування об'єднаних сил, що призводить до зайвої деталізації оперативно-бойових документів, втрати гнучкості, оперативності і в цілому порушує принципи НАТО щодо чіткого розподілу повноважень у відповідних сфеpax відповідальності та принципу Mission Command; - існує тенденція до розглядання операційного 
Командування ПС в якості складової пункту управління Командування об'єднаних сил, а не як окремого органу управління 3 функціями загального планування, управління та координації збройної боротьби в повітряному просторі;

- 3 метою “вибудови вертикалей управління" до складу органів управління застосуванням включаються структурні підрозділи, які є зайвими на від- повідних ланках ієрархії (як то підрозділи підготовки, ресурсів, тощо).

Щодо органів управління генеруванням, їх структура також як правило уніфікована з типовими структурами штабів. Так само, як і в органах управління застосуванням провідну роль відіграють структури А5 та А3, а також підрозділи А7 та А8. Водночас зміст їх діяльності дещо інший (рис. 7).

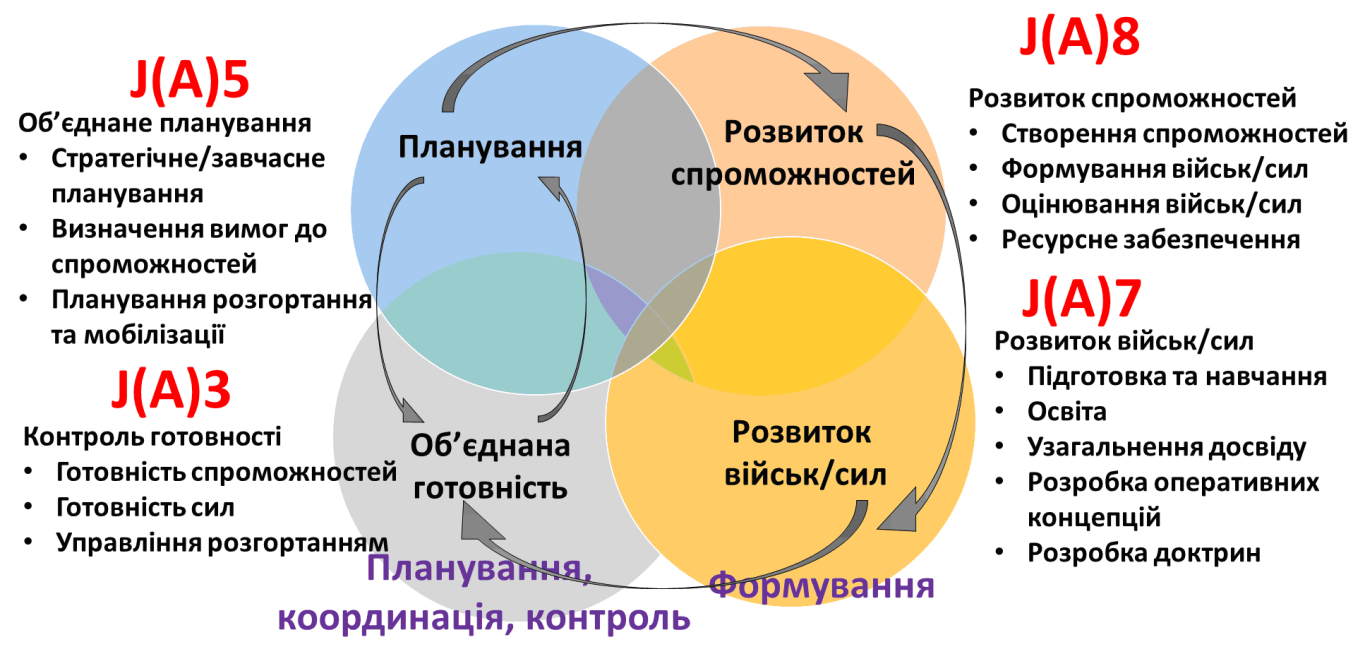

Рис. 7. Розподіл відповідальності основних структурних підрозділів ОВУ генеруванням Джерело: розроблено авторами.

Так, як і в органах управління генеруванням провідну роль в організації роботи штабу відіграє структурний підрозділ планування А5, який здійснює оцінку викликів і загроз на різних горизонтах планування, завчасне планування за сценаріями розвитку безпекового середовища, висуває вимоги до необхідних для реагування на потенційні кризові ситуації спроможностей, планує оперативне (стратегічне) та мобілізаційне розгортання військ. Зазначені оцінки, вимоги та плани є вихідними даними для роботи решти структурних підрозділів органів військового управління.

Так, підрозділ розвитку спроможностей (А8) на підставі визначених вимог до спроможностей забезпечує їх розвиток та створення, формує відповідну структуру військ (сил), здійснює оцінювання їх відповідності сценаріям застосування та здійснює ресурсне забезпечення їх розвитку.

В свою чергу, структурний підрозділ підготовки А7 забезпечує освіту і навчання персоналу для сформованого комплекту військ, організовує його бойову підготовку. Крім того, цей підрозділ, грунтуючись на аналізі та узагальнені досвіду, оцінці форм і способів ведення майбутніх бойових дій формує оперативні концепції застосування, а також доктринальну базу, що регламентують форми, способи та практики застосування. На рівні командувань видів підрозділ А7 може поділятися на штабний (безпосередньо A7) та виконавчий (TRADOC) елемент.

Структурний підрозділ А3 здійснює оперативний моніторинг та контроль готовності сформованого (визначеного) комплекту військ (сил) до виконання завдань за призначенням та організовує оперативне та мобілізаційне розгортання у відповідності до сформованих А5 планів в разі кризової ситуації 3 метою передачі військ в підпорядкування органам управління застосуванням.

Наведений цикл є основним (базовим) управлінських процесом в органах управління генеруванням країн-партнерів.

Слід зазначити, що в ході трансформації системи військового управління ПС ЗС України структура Командування Повітряних Сил як органу управління генеруванням в цілому була приведена до типової структури органів військового управління країн НАТО. Проте трансформаційні процеси є найбільш складними у теорії менеджменту та теорії організації. Отже, при удосконаленні системи військового управління ПС ЗС України виникла низка проблемних питань, робота над якими має продовжуватись:

- внесення зміни в окремі закони України, нормативно-правові акти Кабінету Міністрів України та Міністерства оборони України та їх приведення у відповідність до реорганізованої системи управління;

- необхідність уточнення розподілу функцій i завдань окремих організаційних структур (в першу 
чергу щодо розподілу функцій, завдань і повноважень щодо здійснення оперативного управління (A3), завчасного планування (A5), організації розвитку спроможностей та управління в сфері оборонних ресурсів (А8) між відповідними структурними підрозділами, що наразі не в повній мірі відповідає принципам побудови та роботи штабів в країнах членах НАТО).

\section{Висновки}

Процеси удосконалення системи військового управління 3С України спрямовані на те, щоб у ЗС став властивий високий рівень гнучкості та адаптивності, і вони були здатні виконувати завдання різного характеру для будь-якого сценарію розвитку подій, які можуть виникнути в майбутньому.

При цьому удосконалення системи військового управління є невпинним процесом, і хоча Програма трансформації $є$ завершеною, подальше удосконалення системи військового управління та набуття взаємосумісності з країнами партнерами продовжується. Зокрема в рамках зазначеного процесу з метою удосконалення системи військового управління
ПС ЗС України та набуття взаємосумістності з країнами-членами НАТО необхідно:

- забезпечити впровадження в практику управлінської діяльності такого принципу НАТО як Mission Command;

- продовжити роботу щодо уточнення управлінських процесів, зокрема в частині щодо більш повного розмежування функцій генерування та застосування;

- продовжувати роботу уточнення структури та розподілу функцій і завдань органів військового правління;

- продовжувати роботу щодо більш повної імплементації стандартів та процедур НАТО в системі доктринальних документів 3С України, впровадження відповідних управлінських процесів в повсякденну діяльність та набуття процедурної сумісності;

- зосередити увагу на підготовці особового складу органів військового управління до роботи у нових структурах, набуття ним необхідних знань, умінь та навичок.

\section{Список літератури}

1. Офіційний сайт HROMADSKE.UA. Україна не може вічно бути у залі очікування: Володимир Зеленський закликав прийняти Україну в НАТО та ЄС. - Режим доступу: https://hromadske.ua/posts/ukrayina-ne-mozhe-vichno-buti-uzali-ochikuvannya-zelenskij-zaklikav-prijnyati-ukrayinu-v-nato-ta-yes (дата звертання 22.04.2021).

2. Закон України “Про засади внутрішньої і зовнішньої політики № 2411-VI від 01.07.2010 р."

3. Указ Президента України “Про Стратегію воєнної безпеки України № 121 від 25.03.2021 p.”

4. Дузь-Крятченко О.П. Основи стратегії національної безпеки та оборони держави / О.П. Дузь-Крятченко та ін. К.: НУОУ ім. І. Черняховського, $2015-620$ с.

5. Друкер П. Менеджмент. Вызовы ХХІ века / П. Друкер. - М.: “Манн, Иванов и Фербер”, 2012. - 256 с.

6. Паршин С.А. Современные тенденции развития теории и практики управления в вооруженных силах США / С.А. Паршин, Ю.Е. Горбачев, Ю.А. Кожанов. - М.: ЛЕНАНД, 2009. - 272 с.

7. Теорія прийняття рішень органами військового управління: монографія / В.І. Ткаченко, Г.А. Дробаха, С.Б. Смірнов, А.В. Тристан. - Х.: ХУ ПС, 2008. - 545 с.

8. Warden J. The Enemy as a System / J. Warden // Airpower Journal. - 1995. - № 1. - P. 40-55.

9. AJP-3 (B) Allied joint doctrine for the conduct of operations [Електронний ресурс]. - Washington: Nato Standardization Office, 2019. $\quad$ - $\quad 164 \quad$ p. $\quad$ - $\quad$ Режим доступу: https://assets.publishing.service.gov.uk/government/uploads/system/uploads/attachment_data/file/797323/doctrine_nato_conduct of_ops_ajp_3.pdf.

10. AJP-5 Allied joint doctrine for operational-level planning [Електронний ресурс]. - 2013. - 299 р. - Режим доступу: $\mathrm{http} / /$ www.defencesynergia.co.uk/wp-content/uploads/2016/08/NATO-Allied-Joint-Doctrine-for-Operational-level-planningwith-UK-elements-2013.pdf.

11. STANAG 3700/AJP-3.3 Allied Joint Doctrine for Air and Space Operations [Електронний ресурс]. - Washington: Nato Standardization Office, 2016. - 100 p. - Режим доступу: https://assets.publishing.service.gov.uk/government/ uploads/system/uploads/attachment_data/file/624137/doctrine_nato_air_space_ops_ajp_3_3.pdf.

12. ВКП 1-009(12).01. Доктрина Повітряні Сили Збройних Сил України, Затверджена Головнокомандувачем Збройних Сил України 30.11.2020. - Вінниця: Командування ПС ЗСУ, 2020. - Режим доступу: http://www.hups.mil.gov.ua/assets/uploads/library/nadhodzhennya/sichen-berezen-2021/pdf/28.pdf. 
Відомості про авторів:

Шамко В'ячеслав Свгенович

начальник штабу - заступник командувача

Повітряних Сил Збройних Сил України,

Вінниця, Україна

https://orcid.org/0000-0002-6305-8221

\author{
Антонов Артем Віталійович \\ начальник воєнно-наукового відділу \\ штабу Командування Повітряних Сил \\ Збройних Сил України, \\ Вінниця, Україна \\ https://orcid.org/0000-0002-4172-4318
}

Information about the authors:

Viacheslav Shamko

Chief of Staff - First Deputy Air Force Commander

of the Armed Forces of Ukraine,

Vinnytsia, Ukraine

https://orcid.org/0000-0002-6305-8221

\author{
Artem Antonov \\ Head of the Military-Scientific Department \\ Headquarters of the Air Force Command \\ of the Armed Forces of Ukraine, \\ Vinnytsia, Ukraine \\ https://orcid.org/0000-0002-4172-4318
}

\title{
ВОПРОСЫ ТРАНСФОРМАЦИИ СИСТЕМЫ ВОЕННОГО УПРАВЛЕНИЯ ВОЗДУШНЫХ СИЛ ВООРУЖЕННЫХ СИЛ УКРАИНЫ НА ПУТИ ПРИОБРЕТЕНИЯ ВЗАИМОСОВМЕСТИМОСТИ СО СТРАНАМИ-ЧЛЕНАМИ НАТО
}

\author{
В.Е. Шамко, А.В. Антонов
}

В статье проведен анализ основных результатов трансформации системы военного управления Воздушных Сил 6 2019-2020 годах с позиции приобретения совместимости с системой военного управления НАТО. Раскрыта сущность совершенствования системы военного управления Воздушных Сил Вооруженных Сил Украины, основные задачи, выполненные мероприятия, направления дальнейших действий по обретению совместимости.

Ключевые слова: адаптация, взаимосовместимость, Воздуиные Силь, система управления.

\section{ISSUES OF TRANSFORMATION OF THE MILITARY CONTROL SYSTEM OF THE AIR FORCES OF THE ARMED FORCES OF UKRAINE ON THE WAY OF ACCESSIBILITY WITH THE NATO MEMBER COUNTRIES}

\section{Shamko, A. Antonov}

The article identifies that the transformation of the control system of the Air Force of the Armed Forces of Ukraine is an important step towards the movement of the Armed Forces of Ukraine to NATO. The aggression of the Russian Federation against our country, the occupation of the Autonomous Republic of Crimea and certain districts of Donetsk and Luhansk oblasts, seven years of the Anti-Terrorist Operation (Joint Forces operation) created a public demand for the creation of Ukraine's members in Euro-Atlantic communities and ways of life that offended the people of Ukraine. Acquisition of NATO membership is a norm enshrined in the Constitution of Ukraine and other legal acts. But this path is difficult due to a number of political, economic and military external and internal factors, in particular the inconsistency of the principles of construction and operation of the joint command and control of defense and military management in the Armed Forces of Ukraine and NATO. It is proved that the processes of improving the system of military management of the Armed Forces of Ukraine are aimed at making them flexible and adaptable, able to perform tasks of different nature for any scenario of events that may occur in the future. At the same time, the improvement of the military management system is an ongoing process, and although the Transformation Program is complete, further improvement of the military management system and gaining interoperability with partner countries continues. In particular, in the framework of this process, in order to improve the military management system of the Air Force of the Armed Forces of Ukraine and to achieve interoperability with NATO member countries, it is necessary to: - to ensure the implementation of such a NATO principle as Mission Command in the practice of management; - to continue work on clarification of management processes, in particular in the part on fuller delimitation of functions of generation and application; - to continue the work of clarifying the structure and distribution of functions and tasks of military government bodies; -continue work on the fuller implementation of NATO standards and procedures in the system of doctrinal documents of the Armed Forces of Ukraine, the implementation of appropriate management processes in day-to-day operations and the acquisition of procedural compatibility; - to focus on the preparation of military personnel to work in new structures, the acquisition of the necessary knowledge, skills and abilities.

Keywords: adaptation, interoperability, Air Force, control system. 